\title{
MANAJEMEN BIMBINGAN DAN KONSELING DI SMAN 4 YOGYAKARTA
}

\author{
Arusma Linda Simamora, Suwarjo \\ Program Studi Manajemen Pendidikan PPs UNY, UNY \\ alindamora@gmail.com
}

\begin{abstract}
Abstrak
Tujuan penelitian ini adalah untuk mengungkap manajemen bimbingan dan konseling di SMAN 4 Yogyakarta. Penelitian ini menggunakan pendekatan kualitatif. Jenis penelitian adalah studi kasus. Pengumpulan data menggunakan teknik observasi, wawancara dan studi dokumen. Instrumen penelitian adalah peneliti sendiri. Analisis yang digunakan dalam penelitian ini adalah model analisis interaktif dari Miles dan Huberman melalui kegiatan pengumpulan data, reduksi data, penyajian data, dan penarikan kesimpulan. Hasil penelitian menunjukkan sebagai berikut: manajemen bimbingan dan konseling di SMAN 4 Yogyakarta terdiri atas perencanaan, pengorganisasian, pelaksanaan, dan pengawasan, belum semuanya dilakukan optimal. (1) Perencanaan program BK didasarkan pada analisis kebutuhan siswa, bersifat fleksibel, namun belum berdasarkan analisis lingkungan (2) Pengorganisasian BK, pembagian tugas sesuai dengan mekanisme namun terkendala waktu karena banyak tugas guru BK di luar BK, konselor dan konseli belum seimbang. (3) Pelaksanaan BK, belum menggunakan model BK komprehensif, beberapa layanan belum dilakukan optimal karena banyaknya tugas guru BK di luar kegiatan BK. (4) Pengawasan BK belum dilakukan optimal sebagaimana mestinya.
\end{abstract}

Kata kunci: manajemen bimbingan dan konseling

\section{THE GUIDANCE AND COUNSELING MANAGEMENT IN SMAN 4 YOGYAKARTA}

\begin{abstract}
This study aims to describe the guidance and counseling management in SMAN 4 Yogyakarta. This study employed the qualitative approach and it was case study. The data were collected through observations, interviews, and documents. The research document was researcher herself. The data were analyzed using an analysis model bay Miles and Huberman through the stages of data collection, data reduction, data display, and conclusion drawing. The research findings are as following. The guidance and counseling management in SMAN 4 Yogyakarta consist of: planning, organizing, implementing, and supervising, and all have not been implemented optimally. (1) The plan of the guidance and counseling programs are based on the analysis of student needs, flexible, but not based on analysis of the environmental analysis of students' needs, (2) organizing guidance and counseling, division of tasks in accordance with the mechanism but due to time constraints many tasks of counselor outside the guidance and counseling, counselor and counselee has not been balanced, (3) Implementation of guidance and counseling, not yet used comprehensive model, some services have not performed optimally because of the counselor task outside counselor activities. (4) Monitoring guidance and counseling has not performed optimally as it should.
\end{abstract}

Keywords: guidance and counseling management 


\section{Pendahuluan}

Bimbingan merupakan bagian dari program pendidikan yang membantu peserta didik. Seperti dikemukakan Mortensen \& Schmuller dalam Ali, dkk. (2007: 174) bahwa:

Guidance may be defined as that part of the total educational program that helps provide the personal opportunities and specialized staff services by which each individual can develop to the fullest of his abilities and capacities in terms of the democratic idea.

Peserta didik sebagai warga sekolah membutuhkan bantuan karena berada dalam tahap perkembangan, dimana peserta didik mengalami kesulitan dan hambatan akibat dari kurangnya pemahaman terhadap diri sendiri dan juga lingkungannya.

Oleh karena itu, dibutuhkan layanan bimbingan dan konseling yang dapat mengakomodir kebutuhan peserta didik. Seperti model bimbingan dan konseling perkembangan. Mattewson, dalam Yusuf \& Nurihsan (2005: 53) mengatakan bahwa bimbingan dan konseling perkembangan merupakan pandangan mutakhir yang bertitik tolak dari asumsi positif tentang potensi manusia.

Depdiknas (2008: 192) menyebutkan pentingnya layanan bimbingan dan konseling menyangkut upaya memfasilitasi peserta didik agar mampu mengembangkan potensi dirinya atau mencapai tugas-tugas perkembangannya (menyangkut aspek fisik, emosi, intelektual, sosial, dan moral-spiritual). Siswa sebagai elemen utama sekolah merupakan individu yang sedang berkembang sehingga rentan mengalami masalah yang dapat mempengaruhi hasil belajarnya. Oleh sebab itu, kehadiran layanan bimbingan dan konseling di sekolah khususnya SMA menjadi sangat diperlukan namun dalam pelaksanaannya ditemukan berbagai kendala.

Kendalanya, seperti banyak sekolah memiliki guru bimbingan dan konseling berlatar belakang pendidikan bukan bidang bimbingan dan konseling. Belum seimbangnya rasio antara guru bimbingan dan konseling dengan peserta didik, idealnya 1:150. Sesuai dengan Permendiknas Nomor 39 Tahun 2009 tentang Pemenuhan Beban Kerja Guru dan Pengawas Satuan Pendidikan, Pasal 1 ayat 6 menyebutkan bahwa beban mengajar guru bimbingan dan konseling/konselor adalah mengampu bimbingan dan konseling paling sedikit 150 (seratus lima puluh) peserta didik per tahun pada satu atau lebih satuan pendidikan.

Kenyataan di lapangan masih banyak sekolah yang belum mengelola layanan bimbingan dan konseling dengan yang baik. Seperti, menyusun program bimbingan dan konseling tidak berdasarkan studi kelayakan, hasil analisis, dan tidak melibatkan stakeholder sekolah untuk merumuskan rencana program bimbingan dan konseling. Selain itu, sarana dan prasarana yang kurang memadai. Selain itu, masih banyak siswa yang menganggap guru bimbingan dan konseling sebagai polisi sekolah yang kurang bersahabat sehingga takut untuk mengutarakan permasalahannya. Masih ada anggapan yang salah, bahwa membantu peserta didik dalam menghadapai permasalahannya hanya tugas guru bimbingan dan konseling. Selain itu, sekolah masih memberikan tugas-tugas lain kepada konselor selain tugas pokok.

Kondisi di atas juga ditemukan di SMAN 4 Yogyakarta saat dilakukan pengamatan awal. Seperti program bimbingan dan konseling tahun ajaran 2010/2011 dan tahun ajaran 2011/2012 hampir sama, layanan klasikal bimbingan dan konseling hanya satu jam pelajaran per kelas per minggu, rasio antara guru bimbingan dan konseling dan peserta didik belum seimbang. Selain itu, guru bimbingan dan konseling memiliki banyak tugas selain sebagai guru bimbingan dan konseling seperti merangkap sebagai wakil kepala sekolah, merangkap sebagai koordinator KKO (Kelas Khusus Olahraga), dan kegiatan-kegiatan lain. Masih ada guru bimbingan dan konseling yang memiliki latar belakang pendidikan bukan bidang bimbingan dan konseling, sarana dan prasarana 
kurang memadai. Selain itu, masih ada sebagian guru mata pelajaran/wali kelas belum paham hakikat dan tujuan bimbingan dan konseling sehingga mereka menganggap hanya guru bimbingan dan konseling saja yang bertugas untuk membantu siswa. SMAN 4 Yogyakarta mengalami berbagai kendala dalam mengelola layanan bimbingan dan konseling namun layanan tersebut relatif berjalan. Sekolah tersebut bahkan mendapat berbagai prestasi. Prestasi yang diraih beberapa tahun terakhir antara lain juara olahraga, lomba Nasyid, dan lain-lain. Keberhasilan yang diraih diduga tidak lepas dari sumbangan layanan bimbingan dan konseling. Berdasarkan pengamatan peneliti personil bimbingan dan konseling cukup aktif mendampingi siswasiswi dalam berbagai aktifitas. Untuk kegiatan olahraga guru bimbingan dan konseling saat lomba ikut mendampingi siswasiswi kelas khusus olahraga (KKO) ke lokasi lomba memberikan dukungan dan layanan psikologis. Selain itu, guru bimbingan dan konseling terlibat untuk mendampingi siswa-siswi (KKO) dalam latihan setiap pagi. Selain itu, guru bimbingan dan konseling bekerjsama dengan guru olahraga, orang tua, dan dengan pihak-pihak yang terlibat dalam kegiatan yang dilakukan KKO. Selain itu, dua orang guru bimbingan dan konseling merupakan pengelola $\mathrm{KKO}$, salah satunya menjadi koordinator $\mathrm{KKO}$, tentu kedua guru tersebut banyak terlibat dalam berbagai kegiatan KKO dalam mencapai keberhasilan.

Keterlibatan guru bimbingan dan konseling dalam kegiatan lain seperti Nasyid dan menulis esai adalah memfasilitasi siswa-siswi melalui kegiatan ekstrakurikuler bekerjasama dengan pembina ekstrakurikuler. Selain itu, guru bimbingan dan konseling bekerjasama dengan orang tua, guru mata pelajaran, dan juga dengan berbagai pihak yang mendukung kegiatankegiatan lomba tersebut. Selain itu, salah satu dari guru bimbingan dan konseling setiap pagi membangunkan siswa-siswi untuk ibadah sholat subuh melalui sosial media dan pesan singkat. Menurut peneliti, ini merupakan dukungan yang luar biasa kepada peserta didik untuk mendekatkan diri dengan Tuhan.

Berdasarkan pemaparan di atas, diketahui bahwa personil bimbingan dan konseling kurang dari sisi jumlah, dari sisi tugas tambahan mereka memiliki banyak tugas-tugas selain tugas pokok sebagai guru bimbingan dan konseling, masih ada guru bimbingan dan konseling yang berlatar belakang bukan bidang bimbingan dan konseling. Meskipun demikian, SMAN 4 Yogyakarta mampu memperoleh prestasi yang gemilang. Oleh karena itu, peneliti merasa tertarik untuk meneliti lebih jauh tentang manajemen bimbingan dan konseling di SMAN 4 Yogyakarta.

UU Nomor 20 Tahun 2003 tentang Sistem Pendidikan Nasional dan Permendiknas Nomor 39 Tahun 2009 tentang Pemenuhan Beban Kerja Guru dan Pengawas Satuan Pendidikan, Pasal 1 ayat 6 dilakukan agar layanan bimbingan dan konseling dapat dikelola dengan baik. Maka, dalam mengelola bimbingan dan konseling hendaknya menjalankan fungsi-fungsi manajemen. Seperti yang dikemukakan oleh Terry (1977: 4) mengatakan bahwa "ada empat fungsi manajemen yaitu perencanaan, pengorganisasian, pelaksanaan, dan pengawasan".

Terry (1977: 4) mengatakan bahwa manajemen adalah:

Management is a distinct process consisting of planning, organizing, actuating, and controlling, performed to determine and accomplish stated objectives by the use human beings and other resources. The basic resources are subjected to the fundamental functions of management-planning, organizing, actuating, and controlling in order that the stated objectives are achieved.

Perencanaan merupakan fungsi paling awal dari keseluruhan fungsi manajemen, sebagaimana dikemukakan Usman (2011: 65) berikut ini. Perencanaan ialah sejumlah kegiatan yang ditentukan sebelumnya untuk dilaksanakan pada suatu periode tertentu dalam rangka mencapai tujuan yang ditetapkan". Sementara Griffin (1990: 161) berpendapat bahwa "planning is 
a comprehensive process that includes setting goals, developing plans, and related activities".

Pengorganisasian merupakan kegiatan menyusun dan membentuk hubungan kerja antara personel yang terlibat dalam kesatuan usaha bersama dalam mencapai tujuan yang telah ditetapkan. Seperti yang dikemukakan Rue \& Byars (2000:7) mengatakan berikut ini. "Organizing is grouping activities, assigning activities, and providing the authority necessary to carry out the activities".

Terry (1977: 481) menyebutkan bahwa pengawasan adalah Controlling is determining what is to be accomplished, that is, the standard; what is being accomplished, that is, the performance; evaluating the performance; and if necessary applying corrective measures so that performance takes place according to plans. Pengawasan adalah penentuan apa yang harus dicapai, standar apa yang sedang dicapai, yaitu pelaksanaan, evaluasi pelaksanaan; dan bila perlu melakukan tindakan-tindakan korektif sehingga pelaksanaan menjadi sesuai dengan rencana.

Pengertian Bimbingan dan Konseling

Bimbingan merupakan proses pemberian bantuan kepada konseli yang dilakukan oleh professional yaitu konselor. Sesuai dengan PP Nomor 29 Tahun 1990 Bab X Pasal 27 menyatakan bahwa bimbingan merupakan bantuan yang diberikan kepada siswa dalam rangka upaya menemukan pribadi, mengenal lingkungan dan merencanakan masa depan.

Jones (1970: 7) mengemukakan berikut ini. Guidance is the help given by one person to another in making choice and adjustment and in solving problems. Guidance aims at aiding the recipient to grow in his independence and ability to be responsible for himself. Jones menegaskan bahwa bimbingan adalah bantuan yang diberikan seseorang kepada orang lain dalam memantapkan pilihan dan dalam memecahkan masalah. Bimbingan diberikan agar orang dapat lebih mandiri.

Muro \& Dinkmeyer (1977: 15) mengatakan bahwa "counseling is a personal relationship between a professionally trained counselor and a child which assists the child to communicate and meet immediate and future needs". Menurut Hackney \& Nye (1973: 5) pengertian konseling adalah "Counseling is the helping relationship, which includes (1) someone seeking help, (2) someone willing to give help, who is (3) capable of, or trained to, help (4) in a setting which permits that help to be given and received".

Paparan di atas menguraikan makna dari bimbingan dan konseling secara terpisah. Namun kedua istilah tersebut menjadi satu kesatuan dan saling bergantung dalam pelaksanaanya. Seperti tertuang dalam SK Mendikbud Nomor 025/ O/1995 tentang Petunjuk Teknis Ketentuan Pelaksanaan Jabatan Fungsional Guru dan Angka Kreditnya mengatakan bahwa:

Bimbingan dan konseling adalah pelayanan bantuan untuk peserta didik baik secara perorangan maupun kelompok, agar mampu mandiri dan berkembang secara optimal, dalam bidang bimbingan pribadi, bimbingan sosial, bombingan belajar, dan bimbingan karier, melalui berbagai jenis layanan dan kegiatan pendukung, berdasarkan normanorma yang berlaku.

Bimbingan dan konseling bertujuan untuk membantu peserta didik agar berkembang optimal sesuai tugas perkembangannya. Sukmadinata (2007: 74) mengatakan bahwa tujuan bimbingan dan konseling berikut ini. Bantuan mengoptimalkan perkembangan individu (peserta didik) adalah membantu meningkatkan potensi dan kecakapan yang dimiliki dalam mencari, memanfaatkan fasilitas yang ada di lingkungan. Selanjutnya Depdiknas (2008: 194) mengatakan bahwa: dasar pemikiran penyelenggaraan bimbingan dan konseling di sekolah adalah menyangkut upaya memfasilitasi peserta didik (konseli), agar mampu mengembangkan potensi dirinya atau mencapai tugas-tugas perkembangannya, menyangkut aspek fisik, emosi, intelektual, sosial dan moral spiritual.

Komponen program bimbingan dan konseling komprehensif dikemukakan 
Muro dan Kottman dalam Yusuf \& Nurihsan (2005: 26) diklasifikasikan ke dalam empat jenis layanan berikut ini. 1) Layanan dasar bimbingan, 2) layanan responsive, 3) perencanaan individual, 4) dukungan sistem.

\section{Manajemen Bimbingan dan Konseling}

Perencanaan program bimbingan dan konseling harus dipersiapkan dengan baik karena kegiatan ini bertujuan untuk menentukan program yang akan dilakukan. Sukardi \& Kusmawati (2008: 37) mengatakan bahwa: Studi kelayakan adalah seperangkat kegiatan dalam mengumpulkan berbagai informasi tentang hal-hal yang dibutuhkan untuk penyusunan program bimbingan dan konseling di sekolah. Penyusunan program bimbingan dan konseling harus berdasarkan kebutuhan.

Seperti yang dikemukakan oleh Sukmadinata (2007: 124) berikut ini. Penyusunan program bimbingan dan konseling perlu didasarkan atas kebutuhan-kebutuhan nyata di lapangan. Untuk mengidentifikasi kebutuhan-kebutuhan tersebut perlu diadakan pengumpulan data, baik data primer yang diperoleh langsung dari siswa, orang tua dan guru, maupun data sekunder dari dokumen-dokumen yang ada di sekolah. Sementara itu, Depdiknas (2008: 220) menjelaskan bahwa: Penyusunan program bimbingan dan konseling di sekolah dimulai dari kegiatan asesmen, atau kegiatan mengidentifikasi aspekaspek yang dijadikan bahan masukan bagi penyusunan program tersebut. Kegiatan asesmen meliputi (1) asesmen lingkungan, yang terkait dengan kegiatan mengidentifikasi harapan sekolah dan masyarakat (orang tua peserta didik), sarana dan prasana pendukung program bimbingan dan konseling, kondisi dan kualifikasi konselor, dan kebijakan pimpinan sekolah; dan (2) asesmen kebutuhan atau masalah peserta didik, yang menyangkut karakteristik peserta didik, seperti aspek-aspek fisik (kesehatan dan keberfungsiannya), kecerdasan, motif belajar, sikap dan kebiasaan belajar, minat-minatnya (pekerjaan, jurus- an, olahraga, seni dan keagamaan), masalah-masalah yang dialami, dan kepribadian atau tugas-tugas perkembangan, sebagai landasan untuk memberikan pelayanan bimbingan dan konseling. Selanjutnya, Gysbers \& Henderson (2012: 206) mengatakan bahwa: penilaian kebutuhan tersebut diperoleh dari siswa, pendidik, orang tua, anggota komunitas, pengusaha, dan lulusan.

Pengorganisasian Bimbingan dan Konseling. Penempatan personel bimbingan dan konseling yang tepat dalam organisasi serta pembagian tugas yang tepat. Dalam SK Menpan No. 84/1993 (Prayitno, 2001: 6) ditegaskan bahwa tugas pokok guru bimbingan dan konseling adalah: Menyusun program bimbingan, melaksanakan program bimbingan, evaluasi pelaksanaan bimbingan, analisis hasil pelaksanaan bimbingan, dan tindak lanjut dalam program bimbingan terhadap peserta didik yang menjadi tanggung jawabnya. Selanjutnya, Depdiknas (2008: 233) yang menyatakan bahwa personel utama pelaksanaan bimbingan dan konseling adalah: Konselor dan staf administrasi bimbingan dan konseling. Sementara personel pendukung pelaksana pelayanan bimbingan dan konseling adalah segenap unsur yang terkait dalam pendidikan (kepala sekolah, wakil kepala sekolah, guru mata pelajaran, wali kelas, staf administrasi) di dalam organigram pelayanan bimbingan dan konseling, dengan koordinator dan guru pembimbing/konselor serta staf administrasi bimbingan dan konseling sebagai pelaksana utamanya.

Pelaksanaan bimbingan dan konseling merupakan hal yang sangat penting. Maka, program harus dilakukan seutuhnya sesuai dengan SKB Mendikbud Nomor 0433/P/1993 (Prayitno, 2001: 8) menyebutkan bahwa: Pelaksanaan bimbingan dan konseling adalah melaksanakan fungsi pemahaman, pencegahan, pengentasan, pemeliharaan, dan pengembangan dalam bidang bimbingan pribadi, bimbingan sosial, bimbingan belajar, dan bimbingan karier. 
Dalam pelaksanaan layanan bimbingan dan konseling konselor sebagai personel utama mempunyai beban mengajar. Sesuai dengan Permendiknas Nomor 39 Tahun 2009 Pasal 1 ayat 6 yang menyebutkan beban mengajar guru bimbingan dan konseling/konselor adalah mengampu bimbingan dan konseling paling sedikit 150 (seratus lima puluh) peserta didik per tahun pada satu atau lebih satuan pendidikan. Peserta didik yang berada dalam tanggung jawab guru pembimbing disebut siswa asuh bagi guru pembimbing yang bersangkutan.

Selanjutnya, tugas pokok guru pembimbing perlu dijabarkan ke dalam program-program kegiatan. Nurihsan \& Sudianto (2005: 34) mengatakan program yang telah direncanakan dilaksanakan melalui kegiatan berikut ini. Persiapan pelaksanaan: (a) persiapan fisik (tempat dan perabot), perangkat keras, (b) persiapan bahan, perangkat lunak, (c) persiapan personel, (d) persiapan keterampilan menerapkan/menggunakan metode, teknik khusus, media dan alat, (e) persiapan administrasi. Pelaksanaan kegiatan: (a) penerapan metode, teknik khusus, media dan alat, (b) penyampaian bahan, pemanfaatan sumber alam, (c) pengktifan narasumber, (d) efisiensi waktu, (e) administrasi pelaksana.

Adapun strategi pelaksanaan program untuk masing-masing komponen pelayanan menurut Depdiknas (2008: 224), dapat dijelaskan sebagai berikut ini. Pelayanan dasar meliputi: bimbingan klasikal, pelayanan orientasi, pelayanan informasi, bimbingan kelompok, dan pelayanan pengumpulan data (aplikasi instrumen). Pelayanan responsif meliputi: konseling individual dan kelompok, referral (rujukan atau alih tangan), kolaborasi dengan guru mata pelajaran atau wali kelas, kolaborasi dengan orang tua, kolaborasi dengan pihak-pihak terkait di luar sekolah, konsultasi, bimbingan teman sebaya (peer guidance/peer facilitation), konferensi kasus, kunjungan rumah. Perencanaan individual, dalam layanan ini konselor membantu peserta didik menganalisis kekuatan dan kelemahan dirinya berdasarkan data atau informasi yang diperoleh, yaitu yang menyangkut pencapaian tugas-tugas perkembangan, atau aspek-aspek pribadi, sosial, belajar, dan karier.

Dukungan sistem. Pengembangan profesi. Konselor secara terus menerus berusaha untuk meng-update pengetahuan dan keterampilannya melalui (1) in-service training, (2) aktif dalam organisasi profesi, (3) aktif dalam kegiatan-kegiatan ilmiah, seperti seminar dan workshop (lokakarya), atau (4) melanjutkan studi ke program yang lebih tinggi (Pascasarjana).

Pengawasan merupakan intervensi senior kepada junior, seperti dikemukakan oleh Bernard and Goodyear (Katrina, 2008: 12) "definition of supervision to an intervention provided by a more senior member of a profession to a more junior member or members of that same profession". Selanjutnya, SK Mendikbud Nomor 020/U/1998 dalam Prayitno (2001: 18) mengatakan bahwa: Pengawas sekolah bimbingan dan konseling adalah pengawas sekolah yang mempunyai tugas, tanggung jawab, wewenang, dan hak secara penuh dalam menilai dan membina penyelenggaraan pendidikan pada sejumlah sekolah dalam kegiatan bimbingan dan konseling.

\section{Metode Penelitian}

Jenis Penelitian

Penelitian ini menggunakan pendekatan kualitatif. Jeni penelitian adalah studi kasus.

\section{Waktu dan Tempat Penelitian}

Penelitian dilakukan di SMAN 4 Yogyakarta yang beralamat di Jln. Magelang, Karangwaru Lor, Kecamatan Tegalrejo, Yogyakarta. Perincian waktu penelitian sebagai berikut: bulan Agustus-November 2012 penyusunan dan seminar proposal, penyempurnaan proposal dan proses perizinan penelitian Desember, pengumpulan data di lapangan dan analisis data bulan Februari-April 2013, penyusun- 
an laporan hasil penelitian bulan April-Mei 2013.

\section{Subjek Penelitian}

Subjek penelitian adalah semua guru bimbingan dan konseling, kepala sekolah, waka kurikulum, waka urusan kesiswaan, guru mata pelajaran, wali kelas, siswa, dan orang tua siswa.

Prosedur

Pengumpulan data menggunakan teknik observasi, wawancara, dan studi dokumen. Pengumpulan data menggunakan pedoman observasi, pedoman wawancara, dan pedoman studi dikumentasi. Instrumen penelitian adalah peneliti sendiri.

Teknik Analiasa Data

Analisis yang digunakan dalam penelitian ini adalah model analisis interaktif dari Miles dan Huberman melalui kegiatan pengumpulan data, reduksi data, penyajian data, dan penarikan kesimpulan.

\section{Hasil Penelitian dan Pembahasan}

Hasil penelitian

Perencanaan yang sesuai dengan needs assessment yaitu sudah dilakukan analisis kebutuhan siswa, program direncanakan sesuai dengan visi dan misi sekolah, dilakukan studi kelayakan yaitu dengan menyusun program sesuai dengan program sekolah, mempertimbangkan alokasi waktu belajar efektif, dan juga anggaran. Sudah ada layanan klasikal satu jam pelajaran per kelas per minggu. Perencanaan ketenagaan dengan membagi siswa asuh sesuai dengan ketentuan yang berlaku yaitu minimal mengampu 150 siswa.

Perencanaan yang belum sesuai dengan kaidah yang berlaku seperti belum melakukan asesmen lingkungan, alokasi waktu kontak langsung secara klasikal hanya satu jam pelajaran per kelas per minggu, personil bimbingan dan konseling masih ada yang berlatar belakang pendidikan nonbimbingan dan konseling, pe- rencanaan prasarana belum sesuai dengan ketentuan yaitu ruangan hanya dibatasi oleh kayu pembatas, dan komponen program belum sesuai dengan komponen bimbingan dan konseling komprehensif.

Proses penyusunan perencanaan bimbingan dan konseling dilakukan di awal tahun. Program bimbingan dan konseling disusun oleh guru bimbingan dan konseling di bawah koordinator bimbingan dan konseling selanjutnya diajukan ke kepala sekolah untuk mendapatkan persetujuan.

Penyusunan perencanaan bimbingan dan konseling dari sisi sekolah hanya membagi siswa sesuai dengan plafon yang ditetapkan dalam surat edaran bersama yaitu minimal mengampu 150 siswa. Jumlah siswa yang ada 714 diampu oleh 3 orang guru bimbingan dan seorang waka artinya masih ada sisa 184 siswa. Dasar yang digunakan oleh guru bimbingan dan konseling untuk menyusun program bimbingan dan konseling adalah hasil assesmen kebutuhan peserta didik, visi \& misi sekolah, dan tugas perkembangan siswa.

Menyusun program bimbingan dan konseling belum bisa dilakukan duduk bersama dengan stakeholder sekolah untuk membahas perencanaan program bimbingan dan konseling. Sarana dan prasarana belum memadai. Ruang BK berukuran $6 x$ 6 meter yang terdiri dari: ruang kerja guru $\mathrm{BK}$, ruang bimbingan kelompok, ruang konseling individual, dan ruang tamu BK. Seluruh ruangan menyatu dan hanya dibatasi kayu untuk memisahkan setiap ruangan. Kondisi tersebut tidak nyaman bagi siswa jika melakukan konseling individual karena terdengar ke ruang lainnya apabila berbicara. Namun guru BK menyiasati dengan melakukan konseling di ruangan lain seperti ruang perpustakaan, ruang AVA, dan ruangan lainnya yang tidak dipakai. Selain itu, melakukan konseling di luar sekolah atau memilih waktu yang tepat seperti pagi hari atau sore hari di ruang BK.

Ruang bimbingan kelompok seharihari digunakan untuk ibadah/sholat para guru padahal ada mushola di lantai 2 se- 
kolah yang bisa digunakan untuk ibadah. Ruangan bimbingan kelompok dialihfungsikan akibatnya ruangan tersebut belum dapat digunakan secara maksimal sesuai dengan fungsinya.

Pengorganisasian bimbingan dan konseling di SMAN 4 Yogyakarta. Mekanisme pembagian tugas guru BK dalam membimbing siswa dibagi sesuai dengan ketentuan yaitu minimal mengampu 150 siswa. Siswa sebanyak 714 orang diampu oleh 3 guru bimbingan dan konseling dan seorang waka, maka dan tersisa 184 orang. Berikut jumlah siswa asuh yang diampu guru BK, koordinator BK mengampu 184 siswa, guru BK E mengampu 150 siswa, guru BK B mengampu 195 siswa, dan guru BK A mengampu 185 siswa. Dengan demikian terdapat kelebihan 34 siswa untuk koordinator BK, kelebihan 45 siswa untuk guru BK B, kelebihan 70 siswa untuk guru bimbingan dan konseling $\mathrm{E}$, dan kelebihan 35 siswa untuk guru BK A. Deskripsi tugas personil BK dibagi berdasarkan siswa asuh, kemudian akhir tahun membuat laporan sesuai dengan siswa asuh yang diampunya. Tugas guru BK tidak hanya guru BK saja tetapi masih ada tugas lain yang diberikan oleh kepala sekolah yaitu, koordinator BK merangkap, tim PPKS (Program Penguasaan Kompetensi Siswa), dan tim pendalaman materi. Guru BK E merangkap waka Humas, pengelola KKO, ketua MGP, dan sektretaris komite. Guru BK B merangkap wali kelas. Guru BK A merangkap koordinator $\mathrm{KKO}$, wali kelas, pembimbing Foranza. Layanan BK SMAN 4 Yogyakarta dikelola oleh 4 guru BK, 3 orang guru BK memiliki latar belakang pendidikan yang sesuai dengan bidangnya, yaitu lulusan sarjana pendidikan BK. Sedangkan, seorang dari guru BK berlatar belakang pendidikan administrasi pendidikan.

Kendala dalam pengorganisasian adalah kurangnya waktu karena aktifitas personil BK. Selain itu, tanggung jawab guru BK di luar BK juga banyak. Selain itu, kurangnya kesadaran personil BK akan tugasnya, kurang dukungan, dan kurang komunikasi. Kondisi-kondisi tersebut menyebabkan koordinasi sulit dilakukan.
Pelaksanaan program BK sudah berjalan dengan adanya jam masuk kelas untuk melakukan layanan klasikal secara regular satu jam pelajaran per kelas per minggu. Selain itu, terdapat beberapa layanan yang dilaksanakan secara insidental. Pelaksanaan program fleksibel, artinya layanan yang prioritas yang diselesaikan terlebih dahulu. Jenis layanan yang dilakukan yaitu: a) layanan dasar terdiri dari layanan orientasi, layanan informasi, layanan penempatan \& penyaluran, layanan penguasaan konten, b) layanan responsif terdiri dari layanan konseling perorangan, layanan bimbingan kelompok, layanan konseling kelompok, layanan konsultasi, dan layanan mediasi, c) kegiatan pendukung terdiri dari aplikasi instrumen, himpunan data, konferensi kasus, alih tangan kasus, kunjungan rumah, dan tampilan kepustakaan.

Hambatan dalam pelaksanaan program BK adalah masalah pengorganisasian seperti kurangnya kerjasama, kurangnya kesadaran personil BK, kurangnya pemahaman stakeholder akan tugasnya guru BK. Selain itu, penugasan yaitu banyaknya tugas guru BK di luar tugas pokok guru BK yang menghabiskan banyak waktu. Akibatnya, sulit koordinasi, konseling hanya lewat telepon dan sms, tidak bisa mengerjakan administrasi. Cara mengatasi hambatan dengan meningkatkan kerja sama sesama personil BK, menyesuaikan kondisi, dan melakukan pertemuan nonformal.

Pengawasan BK di SMAN 4 Yogyakarta. Pengawasan terhadap pelaksanaan program BK sudah dilakukan namun belum optimal. Pengawasan dilakukan dengan cara informal dan sifatnya monitoring. Pengawasan internal sekolah dilakukan oleh kepala sekolah dan pengawasan dari luar sekolah dilakukan oleh pengawas bimbingan dan konseling SMA dinas pendidikan. Pengawasan dilakukan dengan cara insidental.

Berikut ini pembahasan atas beberapa temuan dalam penelitian ini. 1) Perencanaan bimbingan dan konseling di SMAN 4 Yogyakarta bersifat fleksibel. 
Fleksibel artinya dalam merumuskan program disesuaikan dengan kondisi atau kebutuhan peserta didik berdasarkan penilaian kebutuhan. Perencanaan bimbingan dan konseling juga kontekstual, artinya program kerja disusun sesuai dengan visi dan misi sekolah serta terpadu dengan program kegiatan sekolah.

Perencanaan bimbingan dan konseling belum faktual karena belum melakukan assesmen lingkungan. Kondisi ini belum sesuai dengan yang dirumuskan Depdiknas (2008: 220) yaitu ada dua asesmen yang harus dilakukan sebagai dasar untuk menyusun perencanaan bimbingan dan konseling yaitu assesmen lingkungan dan asesmen kebutuhan atau masalah peserta didik. Menyusun program bimbingan dan konseling dimulai asesmen lingkungan yang terkait dengan kegiatan mengidentifikasi harapan sekolah dan masyarakat (orang tua peserta didik), sarana dan prasarana pendukung program bimbingan, kondisi dan kualifikasi konselor, dan kebijakan pimpinan sekolah. Pendapat senada dengan Gysbers \& Henderson, (2012: 206) mengatakan penilaian kebutuhan diperoleh dari siswa, pendidik, orang tua, anggota komunitas, pengusaha, dan lulusan.

Proses penyusunan perencanaan bimbingan dan konseling dimulai dari studi kelayakan. Studi kelayakan ialah proses mempelajari kelayakan rencana program bimbingan dan konseling yang disusun berdasarkan waktu yang tersedia. Mempertimbangkan waktu belajar efektif karena harus menyesuaikan dengan program sekolah secara keseluruhan. Disamping itu, alokasi waktu kegiatan kontak langsung yang dilakukan secara klasikal satu jam pelajaran per kelas per minggu. Hal ini belum sesuai dengan dirumuskan oleh Depdiknas (2008: 223) yaitu kegiatan kontak langsung secara klasikal dua jam pelajaran per kelas per minggu. Disamping itu, memperhatikan anggaran yang dibutuhkan untuk melaksanakan program. Ketersediaan anggaran harus diperhatikan dalam menyusun program bimbingan dan konseling. Anggaran khusus untuk prog- ram bimbingan dan konseling belum ada tetapi anggaran yang dibutuhkan untuk pelaksanaan program bergabung dengan kesiswaan, kurikulum, kerumahtanggaan, humas, dan sarana \& prasarana yang diperoleh dari RAPBS dan komite.

Rencana program tertuang dalam program tahunan dan semester kemudian dijabarkan lebih detail pada satuan layanan. Pada satuan layanan tercantum jenis layanan, metode layanan, materi layanan, dan lain. Perencanaan ketenagaan, sudah melakukan pembagian siswa asuh berdasarkan kelas dengan mempertimbangkan jumlah siswa yang ada per kelas. Program bimbingan dan konseling dikelola oleh 4 orang guru bimbingan dan konseling, tiga orang guru bimbingan dan konseling memiliki latar belakang guru bimbingan dan konseling, sementara seorang guru bimbingan dan konseling latar belakang pendidikannya Administrasi Pendidikan. Kondisi ini mempengaruhi kinerja personil bimbingan dan konseling menjadi kurang efektif. Hal ini tidak sesuai dengan asas bimbingan dan konseling,

Depdiknas (2008: 206) mengemukakan tentang asas keahlian yaitu yang menghendaki agar pelayanan dan kegiatan bimbingan dan konseling diselenggarakan atas kaidah-kaidah professional. Selain itu, rasio antara peserta didik belum seimbang, 714 peserta didik hanya diampu oleh 4 guru bimbingan dan konseling. Selain itu, tidak sesuai dengan PP Nomor 74 Tahun 2008 tentang Guru yang mengatakan bahwa beban kerja guru bimbingan dan konseling atau konselor yang memperoleh tunjangan profesi dan maslahat tambahan adalah mengampu bimbingan dan konseling paling sedikit 150 (seratus lima puluh) peserta didik per tahun pada satu atau lebih satuan pendidikan. Selanjutnya, Permendiknas Nomor 39 Tahun 2009 tentang Pemenuhan Beban Kerja Guru dan Pengawas Satuan Pendidikan, Pasal 1 ayat 6 menyebutkan bahwa beban mengajar guru bimbingan dan konseling/konselor adalah mengampu bimbingan dan konseling paling sedikit 150 (seratus lima puluh) 
peserta didik per tahun pada satu atau lebih satuan pendidikan.

Perencanaan sarana dan prasarana sebagai pendukung pelaksanaan program bimbingan dan konseling. Sarana dan prasarana belum memadai. Ruang bimbingan dan konseling berukuran $6 \times 6$ meter yang terdiri dari: ruang kerja guru bimbingan dan konseling, ruang bimbingan kelompok, ruang konseling individual, dan ruang tamu bimbingan dan konseling. Seluruh ruangan menyatu dan hanya dibatasi kayu untuk memisahkan setiap ruangan, sehingga jika dilakukan konseling individual di ruangan konseling individual ataupun di ruang konseling kelompok akan terdengar ke seluruh ruangan bimbingan dan konseling. Hal ini tidak sesuai dengan asas bimbingan dan konseling Depdiknas (2008: 204) asas kerahasiaan adalah asas yang menuntut dirahasiakannya segenap data dan keterangan tentang konseli yang menjadi sasaran pelayanan, yaitu data atau keterangan tentang konseli yang menjadi sasaran pelayanan, yaitu data atau keterangan yang tidak boleh dan tidak layak diketahui oleh orang lain. Di samping itu, ketentuan ruang bimbingan dan konseling yang sesuai dengan Depdiknas (2008: 238) terdiri dari ruang tamu, ruang administrasi, ruang konseling individual, ruang bimbingan dan konseling kelompok, ruang biblio terapi, ruang relaksasi/desentralisasi, dan ruang tamu.

Ruang bimbingan dan konseling di SMAN 4 Yogyakarta belum memenuhi syarat standar yang ditentukan. Meski kondisi ruang konseling yang kurang memadai bukan menjadi hambatan guru bimbingan dan konseling melakukan konseling karena layanan konseling bisa dilakukan di ruangan lain seperti ruang perpustakaan, ruang AVA, dan ruangan lainnya yang tidak dipakai. Selain itu, guru bimbingan dan konseling melakukan konseling di luar sekolah. Selain itu, disiasati dengan memilih waktu yang tepat seperti pagi hari atau sore hari di ruang bimbingan dan konseling. Di samping itu, ruang bimbingan kelompok sehari-hari digunakan untuk ibadah/sholat para guru padahal ada mushola di lantai 2 sekolah yang bisa digunakan untuk ibadah. Ruangan bimbingan kelompok dialih fungsikan akibatnya ruangan tersebut belum dapat digunakan secara maksimal sesuai dengan fungsinya.

Berdasarkan pemaparan di atas dapat disimpulkan bahwa perencanaan bimbingan dan konseling SMAN 4 Yogyakarta yang belum sesuai dengan kaidah antara lain belum melakukan asesmen lingkungan, alokasi waktu kontak langsung secara klasikal hanya satu jam pelajaran per kelas per minggu, personil bimbingan dan konseling masih ada yang berlatar belakang pendidikan nonbimbingan dan konseling, perencanaan prasarana belum memadai. Needs assessment sangatlah penting karena dengan dilakukannya analisis kebutuhan maka akan diketahui kebutuhan-kebutuhan yang akan dituangkan dalam program. Sementara, perencanaan yang sudah sesuai dengan kaidah antara lain sudah melakukan asesmen kebutuhan siswa, program disesuaikan dengan visi dan misi sekolah, sudah mencantumkan program yang akan dilakukan, dan terdapat sumber daya yaitu personil bimbingan dan konseling dan sumber dana.

Proses penyusunan bimbingan dan konseling dilakukan di awal tahun. Rencana bimbingan dan konseling disusun oleh guru bimbingan dan konseling lalu diserahkan ke kepala sekolah untuk mendapat persetujuan. Rencana program yang membutuhkan anggaran, seperti mengundang psikolog untuk melakukan tes psikologi dan program lainnya disisipkan di kesiswaan. Untuk mengetahui kebutuhan siswa dilakukan analisis kebutuhan siswa menggunakan alat DCM. Pembagian siswa asuh sesuai dengan kriteria yang berlaku yaitu minimal mengampu 150 siswa asuh dan seluruh siswa yang ada dibagi oleh 4 guru bimbingan dan konseling.

Menyusun program bimbingan dan konseling yang berkaitan dengan anggaran melibatkan semua wakil kepala sekolah. Idealnya, menyusun program bimbingan dan konseling melibatkan stakeholder sekolah untuk merumuskan program bimbingan dan konseling namun yang dilakukan 
hanya kolaborasi secara informal dan parsial. Hal ini belum sesuai dengan yang dirumuskan oleh Depdiknas (2008: 220) mengatakan bahwa penyusunan program bimbingan dan konseling dimulai dengan kegiatan asesmen yaitu asesmen lingkungan dan asesmen kebutuhan siswa. Selanjutnya, belum sesuai juga dengan Sukmadinata (2007: 124) mengatakan bahwa menyusun program bimbingan dan konseling didasarkan atas kebutuhan. Untuk mengidentifikasi kebutuhan-kebutuhan tersebut perlu diadakan pengumpulan data, baik data primer yang diperoleh langsung dari siswa, orang tua dan guru, maupun data sekunder dari dokumendokumen yang ada di sekolah.

Dapat disimpulkan bahwa proses penyusunan program bimbingan dan konseling belum sesuai dengan ketentuan yang ada. 2) Pengorganisasian Bimbingan dan Konseling. Kegiatan dalam pengorganisasian yaitu koordinasi menangani kasus-kasus yang dihadapi peserta didik baik di dalam dan di luar sekolah oleh personil bimbingan dan konseling. Mekanisme pembagian tugas guru bimbingan dan konseling dalam membimbing siswa minimal mengampu 150 siswa. Siswa berjumlah 714 orang yang diampu oleh empat guru bimbingan dan konseling berdasarkan kelas dengan mempertimbangkan jumlah siswa per kelas karena setiap kelas jumlahnya berbeda.

Deskripsi tugas personil bimbingan dan konseling yaitu mengampu siswa asuh yang dibagi berdasarkan kelas berikut ini. Koordinator bimbingan dan konseling mengampu 184 siswa, guru bimbingan dan konseling E mengampu 150 siswa, guru bimbingan dan konseling B mengampu 195 siswa, dan guru bimbingan dan konseling A mengampu 185 siswa. Dengan demikian terdapat kelebihan 34 siswa asuh koordinator, kelebihan 45 siswa guru bimbingan dan konseling B, dan kelebihan 35 siswa guru bimbingan dan konseling $\mathrm{A}$, dan kelebihan 70 siswa asuh guru bimbinagn dan konseling E karena menjabat sebagai waka. Siswa asuh 3 orang guru bimbingan dan konseling berjumlah 450 siswa +80 siswa asuh yang diampu waka $=530$ siswa. Total siswa $714-530=184$ siswa. Terdapat 184 kelebihan siswa yang seharusnya diampu oleh seorang personil lagi. Kondisi tersebut tidak sesuai dengan Permendiknas No. 39 tahun 2009 tentang Pemenuhan Beban Kerja Guru dan Pengawas Satuan Pendidikan, Pasal 1 ayat 6 yang mengatakan bahwa beban mengajar guru bimbingan dan konseling/konselor adalah mengampu bimbingan dan konseling paling sedikit 150 (seratus lima puluh) peserta didik per tahun pada satu atau lebih satuan pendidikan.

Untuk mengantisipasi kondisi ini sesuai dengan rasio personil bimbingan dan konseling dan jumlah siswa sudah selayaknya menambah seorang personil bimbingan dan konseling. Di samping itu, personil bimbingan dan konseling masih memiliki tugas lain di luar guru bimbingan dan konseling. Berikut tugas-tugas yang diemban oleh personil bimbingan dan konseling di luar bimbingan dan konseling. Koordinator bimbingan dan konseling merangkap tim tata tertib, tim PPKS (Program Penguasaan Kompetensi Siswa), dan tim pendalaman materi. Guru bimbingan dan konseling E merangkap waka Humas, pengelola $\mathrm{KKO}$, ketua MGP, dan sektretaris komite. Guru bimbingan dan konseling $B$ merangkap wali kelas. Guru bimbingan dan konseling A merangkap koordinator $\mathrm{KKO}$, wali kelas, pembimbing Foranza. Selain itu, jika ada kegiatan insidental lainnya guru bimbingan dan konseling selalu terlibat.

Kondisi tersebut di atas membuat aktifitas guru bimbingan dan konseling di luar kegiatan bimbingan dan konseling sangat tinggi, akibatnya kegiatan koordinasi antar personil bimbingan dan konseling tidak bisa dilakukan dengan baik karena tidak bisa duduk bersama untuk koordinasi terkendala waktu. Selain itu, tidak bisa melakukan kegiatan layanan bimbingan dan konseling dengan optimal. Kondisi tersebut tidak sesuai dengan SK Menpan No. 84/1993 (Prayitno, 2001: 6) yang mengatakan bahwa tugas pokok guru bimbingan dan konseling adalah "menyu- 
sun program bimbingan, melaksanakan program bimbingan, evaluasi pelaksanaan bimbingan, analisis hasil pelaksanaan bimbingan, dan tindak lanjut dalam program bimbingan terhadap peserta didik yang menjadi tanggung jawabnya (Pasal 4).

Layanan bimbingan dan konseling SMAN 4 Yogyakarta dikelola oleh 4 guru bimbingan dan konseling dimana 3 orang guru memiliki latar belakang pendidikan yang sesuai dengan bidangnya, yaitu lulusan sarjana pendidikan bimbingan dan konseling. Sedangkan seorang dari guru bimbingan dan konseling berlatar belakang pendidikan bukan bimbingan dan konseling tetapi administrasi pendidikan. Hal ini tidak sejalan dengan asas keahlian yang dirumuskan oleh Depdiknas (2008: 206) yang mengatakan bahwa bimbingan dan konseling menghendaki agar pelayanan atau kegiatan bimbingan dan konseling diselenggarakan atas dasar kaidah-kaidah professional. Dalam hal ini, para pelaksana pelayanan dan kegiatan bimbingan dan konseling hendaklah tenaga yang benarbenar ahli dalam bimbingan dan konseling. Keprofesionalan guru bimbingan dan konseling harus terwujud baik dalam penyelenggaraan jenis-jenis pelayanan dan kegiatan bimbingan dan konseling maupun penegakan kode etik bimbingan dan konseling.

Kondisi di atas merupakan kendala dalam pengorganisasian bimbingan dan konseling. Beban tugas dan tanggung jawab personil bimbingan dan konseling di luar bimbingan dan konseling sangat banyak, dan hal tersebut mengakibatkan kurangnya waktu untuk melakukan tugas pokok, sulit koordinasi, dan kurang komunikasi. Kendala lain, masih ada guru bimbingan dan konseling yang belum profesional di bidangnya. Kendala lain, kurangnya kesadaran personil akan tugas, kurangnya dukungan. 3) Pelaksanaan Bimbingan dan Konseling. Pelaksanaan program bimbingan dan konseling sudah berjalan dengan adanya jam masuk kelas untuk melakukan layanan klasikal secara regular satu jam pelajaran seminggu. Selain itu, terdapat beberapa layanan yang dilaksanakan secara insidental Pelaksanaan program fleksibel. Jenis layanan dasar yang dilakukan yaitu a) Layanan dasar terdiri dari layanan orientasi, layanan informasi, layanan penempatan \& penyaluran, layanan penguasaan konten, b) layanan responsif terdiri dari layanan konseling perorangan, layanan bimbingan kelompok, layanan konseling kelompok, layanan konsultasi, dan layanan mediasi, c) kegiatan pendukung terdiri dari aplikasi instrumen, himpunan data, konferensi kasus, alih tangan kasus, kunjungan rumah, dan tampilan kepustakaan.

Jenis layanan yang dilakukan belum sesuai dengan yang dirumuskan oleh Depdiknas (2008: 228) layanan dasar terdiri dari: a) Layanan dasar terdiri dari bimbingan kelas, pelayanan orientasi, pelayanan informasi, bimbingan kelompok, dan pelayanan pengumpulan data. b) Layanan responsif terdiri dari konseling individual \& kelompok, referral, kolaborasi dengan guru mata pelajaran/wali kelas, kolaborasi dengan orang tua, kolaborasi dengan pihak-pihak terkait di luar sekolah, konsultasi, bimbingan teman sebaya, konferensi kasus, kunjungan rumah. c) Perencanaan individual. d) Dukungan sistem terdiri dari: pengembangan profesi, manajemen program, dan riset \& pengembangan.

Beberapa layanan sudah dilaksanakan dengan baik seperti, layanan bimbingan kelas, layanan orientasi sudah, layanan informasi Layanan referral. Selain itu, kolaborasi dengan guru mata pelajaran, wali kelas, orang tua dan pihak terkait di luar sekolah sudah dilakukan dengan baik. Selain itu, layanan konferensi kasus, instrumentasi data, dan layanan home visit juga sudah dilaksanakan dengan baik.

Layanan yang belum optimal dilakukan seperti layanan bimbingan kelompok. Meski layanan ini belum dilakukan dengan optimal sebagian materi layanan bimbingan kelompok sudah disampaikan pada saat bimbingan kelas. Materi layanan seperti menyalurkan (bakat, minat \& kegemaran), hidup sehat, dan etika pergaulan \& solidaritas. Hanya saja metode penyampaian tidak sesuai yaitu dengan 
berkelompok. Seperti tertuang di Depdiknas (2008: 225) mengatakan konselor memberikan pelayanan bimbingan kepada peserta didik melalui kelompok-kelompok kecil (5-10 orang). Bimbingan ditujukan untuk merespon kebutuhan dan minat peserta didik.

Layanan konseling individual dan konseling kelompok belum optimal. Kenyataannya layanan konseling individual siswa yang tercover tidak sampai 50\% (wawancara dengan guru bimbingan dan konseling A tanggal 4 Februari 2013). Kondisi ini merugikan siswa karena banyak siswa yang tidak terlayani. Layanan ini sangat dibutuhkan karena membantu siswa yang mengalami permasalahan. Layanan konseling individual ditujukan untuk membantu peserta didik yang mengalami kesulitan, mengalami hambatan dalam mencapai tugas-tugas perkembangannya, Depdiknas (2008: 226).

Layanan bimbingan teman sebaya belum optimal. Layanan bimbingan teman sebaya yang dilakukan adalah Foranza (Forum Anti Napza). Pelaksanaan dari sisi bimbingan dan konseling belum bisa dilaksanakan maksimal.

Pada program tidak terdapat layanan perencanaan individual tetapi layanan penempatan dan penyaluran. Sebagian materi perencanaan individual ada pada layanan penempatan dan penyaluran seperti materi penempatan di kelas, ekstrakurikuler, dan penjurusan. Sebagian materi terdapat pada layanan penguasaan konten, seperti mengambil mengambil keputusan melalui analisis SWOT dan ESQ mendasari perencanaan masa depan. Materi lain juga terdapat pada layanan informasi yaitu perencanaan karir dan analisis potensi diri. Dapat disimpulkan bahwa layanan perencanaan sudah dilakukan hnaya saja materinya tersebar di beberapa jenis layanan.

Kesempatan bagi guru bimbingan dan konseling mengembangkan profesi ada namun belum semua melakukannya. Bentuk pengembangan profesi seperti kegiatan penataran, seminar, pelatihan, kuliah ke jenjang yang lebih tinggi. Riset belum dapat dilakukan. Manajemen program bimbingan dan konseling sudah ada pembagian kerja dan ada program. Namun, mengelola bimbingan dan konseling seperti perencanaan, menganalisis, mengevalusai secara detail belum dapat dilakukan dengan baik. Selain itu, pelaksanaan program berbeda dengan perencanaan.

Hambatan dalam pelaksanaan program bimbingan dan konseling adalah kurangnya kerjasama, kurangnya kesadaran personil bimbingan dan konseling, kurangnya dukungan sistem, kurangnya pemahaman stakeholder akan tugas guru bimbingan dan konseling. Selain itu, banyaknya tugas guru bimbingan dan konseling diluar tugas pokok guru bimbingan dan konseling. Kondisi tersebut mengakibatkan personil bimbingan dan konseling sulit koordinasi, guru bimbingan dan konseling tidak bisa mengerjakan administrasi, dan tugas pokok menjadi terbengkalai. Hal ini dapat terlihat dari beberapa layanan yang tidak dilakukan dengan optimal dan tidak sesuai dengan prosedur yang semestinya. Cara mengatasi hambatan dengan meningkatkan kerja sama sesama personil bimbingan dan konseling dan menyesuaikan kondisi. Berdasarkan pembahasan di atas dapat disimpulkan bahwa SMAN 4 Yogyakarta belum melakukan bimbingan dan konseling komprehensif.

Pengawasan bimbingan dan konseling belum optimal, seharusnya dilakukan pengawasan secara berkala karena pengawasan bertujuan untuk mengetahui sejauh mana layanan terlaksana sesuai rencana. Pengawasan internal dilakukan oleh kepala sekolah. Sedangkan pengawasan eksternal dilakukan oleh pengawas bimbingan dan konseling seperti yang dikemukakan Prayitno, (2001: 2) bahwa pengawasan dari luar yang dilakukan oleh pengawas sekolah terhadap guru pembimbing diharapkan dapat menolong dan mengangkat guru-guru tersebut untuk setiap hari meningkatkan wawasan dan kemampuan fungsional-profesional-keahliannya, khususnya dalam bidang bimbingan dan konseling. Selanjutnya tertuang pada SK Mendikbud No.020/U/1998 (Prayitno, 
2001: 18) yang mengemukakan bahwa pengawas sekolah bimbingan dan konseling adalah pengawas sekolah yang mempunyai tugas, tanggung jawab, we-wenang, dan hak secara penuh dalam menilai dan membina penyelenggaraan pendidikan.

\section{Simpulan dan Saran}

Kesimpulan

Penyusunan perencanaan bimbingan dan konseling berdasarkan studi kelayakan. Menyusun program bimbingan dan konseling belum dilakukan kerjasama dengan stakeholder sekolah. Perencanaan bersifat fleksibel, disesuaikan dengan visi dan misi sekolah serta terpadu dengan kegiatan sekolah, namun belum berdasarkan harapan sekolah dan orang tua. Perencanaan personil belum sesuai standar karena masih ada guru bimbingan dan konseling bukan sarjana bimbingan dan konseling. Perencanaan sarana dan prasarana belum memenuhi syarat karena belum memadai.

Pembagian tugas personil bimbingan dan konseling sudah sesuai mekanisme yaitu minimal mengampu 150 siswa, tetapi rasio antara guru bimbingan dan konseling dengan peserta didik belum seimbang. Total siswa 714 orang diampu oleh 3 guru bimbingan dan konseling dan seorang guru bimbingan dan konseling sekaligus menjabat waka. Terdapat kelebihan 184 siswa yang seharusnya diampu seorang guru bimbingan dan konseling dan belum ada staf yang membantu administrasi bimbingan dan konseling. Kendala dalam pengorganisasian adalah rasio guru bimbingan dan konseling dan peserta didik belum seimbang, masih ada guru bimbingan dan konseling bukan sarjana bimbingan dan konseling, tugas-tugas guru bimbingan dan konseling di luar bimbingan dan konseling banyak, kurangnya kesadaran personil akan tugasnya, kurangnya dukungan, dan sulit koordinasi.

Pelaksanaan sudah berjalan namun belum menggunakan model bimbingan dan konseling komprehensif. Ada layanan klasikal yang dilakukan secara regular yaitu satu jam pelajaran per kelas per minggu. Layanan yang sudah dilakukan adalah layanan bimbingan kelas, layanan orientasi, layanan informasi. Kolaborasi dengan pihak sekolah dan dengan pihak terkait di luar sekolah. Layanan yang belum dilakukan dengan optimal adalah layanan konseling kelompok, layanan bimbingan kelompok, layanan konseling individual, dan layanan teman sebaya.

Kegiatan pendukung yang dilakukan adalah layanan aplikasi instrumentasi, himpunan data, konferensi kasus, home visit, referral, dan tampilan kepustakaan.

Pengawasan dilakukan namun belum optimal. Pengawasan dilakukan secara informal dengan pola monitoring. Pengawasan dilakukan oleh pengawas bidang bimbingan dan konseling yang tugasnya mengawasi bimbingan dan konseling SMA.

\section{Saran}

Berdasarkan hasil analisis disampaikan beberapa saran sebagai berikut:

Aspek perencanaan bimbingan dan konseling di SMAN 4 Yogyakarta, sebaiknya dilakukan asesmen lingkungan sebagai dasar untuk menyusun program. Selain itu, menyusun program bimbingan dan konseling sebaiknya melibatkan stakeholder sekolah. Selain itu, sarana dan prasarana perlu direncanakan dengan baik mengingat sarana dan prasarana menunjang keberhasilan program bimbingan dan konseling.

Aspek pengorganisasian bimbingan dan konseling di SMAN 4 Yogyakarta sebaiknya rasio siswa dan guru bimbingan dan konseling seimbang. Selain itu, sebaiknya ada petugas administrasi yang membantu menangani administrasi bimbingan dan konseling. Selain itu, guru bimbingan dan konseling hendaknya berlatar belakang pendidikan bidang bimbingan dan konseling. Selain itu, tugas guru bimbingan dan konseling sebaiknya tidak lagi ditambah dengan tugas-tugas lain di luar kegiatan bimbingan dan konseling agar dapat optimal melayani peserta didik. 
Aspek pelaksanaan kegiatan bimbingan dan konseling hendaknya semua layanan dilakukan dengan optimal. Selain itu, hendaknya menggunakan model bimbingan dan konseling komprehensif karena melibatkan semua stakeholder sekolah, titik berat layanan terletak pada pencegahan dan pengembangan, memiliki visi pengembangan pada perkembangan optimal dan strategi.

Aspek pengawasan hendaknya kepala sekolah melakukan pengawasan secara periodik terhadap program bimbingan dan konseling. Selain itu, hendaknya dilakukan evaluasi menyeluruh manajemen bimbingan dan konseling secara berkala.

\section{Daftar Pustaka}

Ali, M. dkk. (2007). Ilmu dan aplikasi pendidikan. Bandung: Pedagogiana Press.

Depdiknas. Permendiknas Nomor 27, Tahun 2008, tentang Standar Kualifikasi Akademik dan Kompetensi Konselor.

. Permendiknas Nomor 39, tahun 2009, tentang Pemenuhan Beban Kerja Guru Dan Pengawas Satuan Pendidikan.

(2008). Penataan pendidikan profesional konselor dan layanan bimbingan dan konseling dalam jalur pendidikan formal. Jakarta; BP. Cipta Jaya.

Griffin, R.W. (1990). Management. Houghton: Mifflin Company.

Gysbers, N.C. \& P. Henderson. (2012). Developing and managing your school guidance and counseling program (5th). Alexandria, VA: ACA.

Hackney, H \& Nye, S. (1973). Counseling strategies and objectives. Ney Jersey: Prentice-Hall Inc.

Jones, A.J. (1970). Principles of guidance. New York: McGraw-Hill Book Company.

Katrina, C. (2008). An evaluation of school counselor supervision. Dissertation. University of Texas at San Antonio.
Proquest: Texas. Diambil tanggal 28

Mei 2013 dari http://search.proquest.com/docview /304830706/ 13D95BC 423F2E13 C112/33?accountid=31324.

Miles, M.B. \& Huberman, A.M. (1994). Qualitative data analisis. London: Sage Publications.

Muro, J.J. \& Dinkmeyer, D.C. (1977). Counseling in the elementary and middle schools. A pragmatic approach. USA: Wm. C. Brown Company Publisher.

Nurihsan, A.J. \& Sudianto, A. (2005). Manajemen bimbingan dan konseling di SMA: kurikulum 2004. Jakarta: PT Gramedia Widiasarana Indonesia.

Prayitno. (2001). Panduan kegiatan pengawasan bimbingan dan konseling di sekolah. Jakarta: Rineka Cipta.

Presiden. Peraturan Pemerintah Nomor 74, tahun 2008, tentang Guru.

Rue, L.W. \& Byars, L.L. (2000). Management, skill and application. Ney Work: Mc Graw Hill Companies. Inc.

Republik Indonesia. Undang-Undang Republik Indonesia Nomor 20, tahun 2003, tentang Sistem Pendidikan Nasional.

Sukardi, D.K. \& Kusmawati, D.P.E.N. (2008). Proses bimbingan dan konseling di sekolah. Jakarta: Rineka Cipta.

Sukmadinata, N.S. (2007). Bimbingan dan konseling dalam praktek mengembangkan potensi dan kepribadian siswa. Jakarta: Maestro.

Terry, G.R. (1977). Principles of management. (3rd) Homewood IL: Richard D Irwin, INC.

Usman, H. (2011). Manajemen: teori, praktik, dan riset pendidikan. Jakarta: Bumi Aksara.

Yusuf, S \& Nurihsan, J. (2005). Landasan bimbingan dan konseling. Bandung: Rosdakarya 